\title{
Digging in the dark: reviewing international literature to address impending policy challenges for Swedish and Finnish mining
}

\author{
Gregory Poelzer ${ }^{1}$ (D) $\cdot$ Stefan Linde ${ }^{2} \cdot$ Sverker C. Jagers $^{3} \cdot$ Simon Matti ${ }^{4}$
}

Received: 18 June 2020 / Accepted: 16 February 2021 / Published online: 4 March 2021

(C) The Author(s) 2021

\begin{abstract}
The mining industries of Sweden and Finland currently face several policy issues around investment, stakeholder involvement, and sustainability. Since the two countries garnered significant attention during the mining boom, research from a social sciences perspective grew significantly. One approach to understanding how these issues in Sweden and Finland compare to international examples is through an analysis of the policy development framework. Looking at three factors-institutions, actors, and process - gives a broad overview of the imminent challenges in both Sweden and Finland and potential lessons from existing research that point to similar problems and their solutions. As the mining operations continue to sit at the center of different values, capable policy is required.
\end{abstract}

Keywords Mining policy $\cdot$ Policy process $\cdot$ Institutions

\section{Introduction}

Strong growth in any industry attracts attention from other sectors, such as government, Indigenous groups, NGOs, and academia, as the debate over the consequences follows. Sweden and Finland garnered such attention during the mining boom. Increasing demand for metals and mines drives mineral exploration with the aim of identifying commercially extractable deposits across the EU (European Commission 2016). As the region experienced a proliferation of mineral exploration and investment, various actors raised questions over the viability of mining and its effect on existing social practices and the environment. Academic research on the mining industry grew commensurately and one field that benefit-

Gregory Poelzer

gregory.poelzer@1tu.se

1 Political Science, Department of Social Sciences, Technology and Arts, Luleå University of Technology, 97187 Luleå, Sweden

2 Mid Sweden University, Östersund, Sweden

3 University of Gothenburg, Gothenburg, Sweden

4 Luleå University of Technology, Luleå, Sweden ted considerably from the surge in research is the social sciences. Over the past few years, issues central to the social side of the mining industry, such as CSR, social license, public consultations, and environmental regulation, received far greater examination. Nevertheless, as mining activity continues in these Nordic nations and proposals for new projects are assessed, understanding the mining policy processes from a social science perspective is ever more critical.

From a policy process perspective, mining provides an interesting but not uncommon case of competing interests and values, a non-renewable resource that requires land use and causes irreversible change to the ecosystem but, often, generates significant revenues both for the state and for private actors. Reconciling these values and the multiple interests associated with land use remains a persistent challenge for countries endowed with natural resources, not the least as governments look to stay in power and politicians to get reelected. On the one hand, governments in resource-rich countries must attract investment to ensure that national resource revenue continues while, on the other hand, creating parameters for mining that considers local interests and limits negative effects in the environment as well as on existing sociocultural practices. In political practice, this challenge of balancing or merging the three dimensions of sustainability (e.g., economic, ecological, social) becomes increasingly 
more complex as governments must work within existing institutions and continuously respond to a large, and growing, cast of actors (McMahon and Remy 2001).

Playing a critical role in human development, mining facilitated the advent of modern tools, engineering, and industrya result of both production and downstream activities. Thus, mining remains crucial to our current lifestyle. Furthermore, achieving global and regional goals of sustainability, specifically around carbon emission reduction, necessitates the extraction of new minerals. Meeting these goals still puts pressure on communities, particularly regarding the risk of environmental degradation and substantial societal and cultural change (Bridge 2004: p. 206). Increasingly, local communities demand more action from governments and corporations to protect their sociocultural and economic interests. As a result, governments attempt to enhance the policy process (or elements of it) with more inclusivity while mining companies emphasize corporate social responsibility (CSR) in their efforts to improve community relations (McMahon and Remy 2001). While much of the research on CSR is focused on developing countries, where the legislative and regulatory are typically lacking, the contributions here add to our understanding on how corporate practices can drive political institutional change (Frederiksen 2019) and contribute to trust building within the community (Cesar and Jhony 2020) or, alternatively, fail to deliver on its promise and perpetuate historical problems (Hilson et al. 2019). Finally, an important aspect of CSR and mining is with reference on impacts to Indigenous communities, particularly the potential economic benefits that come with company-community partnerships (Berman et al. 2020). The connection between CSR and partnerships is particularly pertinent to Sweden and Finland, which are both home to Sami in the north. Again, while the importance of these engagement and feedback mechanisms for securing local benefits is acute in developing states with weak institutions, these issues remain pertinent for jurisdictions, such as the Nordics, that are engaged in debates over the benefits and costs of mineral extraction. Often regarded as progressive countries in terms of environmental stewardship and human welfare, an opportunity to learn from international examples and ensure mining policy fulfills societal goals.

This article aims to complete three tasks First, laying out the key facets of policy analysis - institutions, actors, and processes - and their importance in respect to mining development, then categorizing the existing body of work as a starting point to determine future areas of research. Second, highlighting key issues in Sweden and Finland related to each of the institutions, actors and process, point out some of the practical implications, and the strategies used to either take advantage of opportunities or mitigate problems. This includes highlighting similar problems experienced at different locations across the globe. Third, assessing the findings of the review and highlighting areas of strength in the policy and pointing to keys areas that we believe would benefit from additional attention.

\section{Analysis model}

Understanding policy development remains one of the central points of departure for research in public policy processes in general and political science. While various concepts on policy creation exist, describing the institutions, identifying the actors, and outlining the process serve as three of the more prominent points of analysis when looking at policy frameworks. However, when making the connection between policy analysis and international lessons from the mining sector, acceptance is a useful concept to build around as it serves as one of the central themes of research in the form of social license to operate (SLO).

The concept of SLO was originally intended as a concept for companies to follow to develop trust in the communities affected by operations (Thomson and Boutilier 2011), but the scope has broadened, and the analysis diversified. While the core philosophy of community relations remains, recement studies dig deeper into the contextual factors such as the history of the company (Ofori and Ofori 2019), the active role for government and knowledge of the socioeconomic landscape (Sícoli Pósleman and Sallan 2019), and the effect of reports from the industry (de-Miguel-Molina et al. 2019) on the relationship building between the company and community. In addition to the nuance on the local level, research on SLO is moving beyond the local level at looking at the implications for legislation (Robinson et al. 2020), and the national (Moffat and Zhang 2014) or regional levels (Lesser et al. 2020). The research path of SLO confirms the importance of assessing institutions, actors, and decision-making as a framework to understand the problem solving in the mineral sector for these two Nordic nations.

While political institutions are understood in different ways, particularly regarding institutional creation and change, an institution is commonly viewed as "the rules of the game" (Peters 2005) and "a relatively enduring collection of rules and organized practices, embedded in structures of meaning and resources that are relatively invariant in the face of turnover of individuals and relatively resilient to the idiosyncratic preferences and expectations of individuals and changing circumstances (March and Olsen 2006: p. 3)," or, as stated more directly by North (1991: p. 97), "Institutions are the humanly devised constraints that structure political, economic and social interaction. They consist of both informal constraints (sanctions, taboos, customs, traditions, and codes of conduct), and formal rules (constitutions, laws, property rights)." As Fig. 1 below illustrates, institutions define the parameters of action-mining development notwithstanding. The formal 


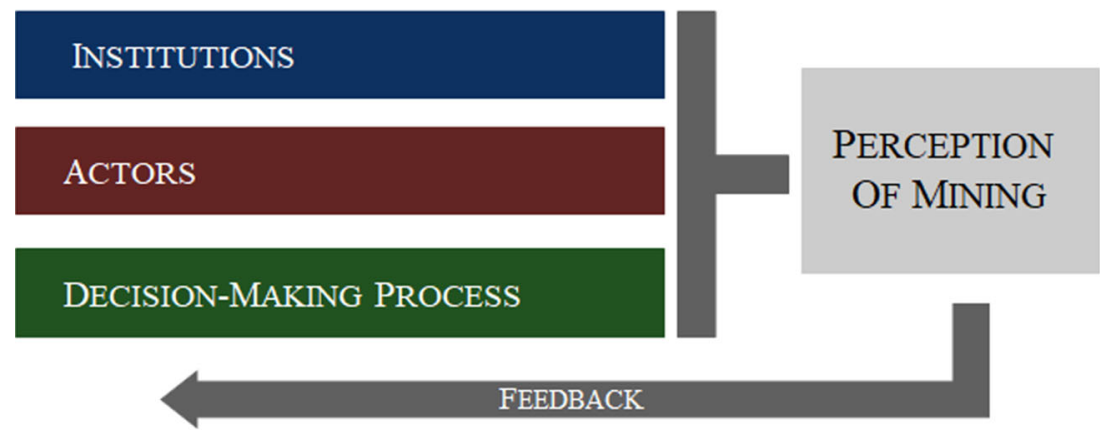

institutions, which include legislation and regulation on multiple levels of government, attempt to lay out the most transparent rules of the game. The informal institutions, such as norms, values, conventions, and culture, shape policy indirectly both by placing external pressure on policy-makers during the decision-making processes and by guiding the degree of discretion for implementing authorities and actors. Thus, institutions determine which actors that are granted access to the process, as well as the resources, tactics, and venues available to them throughout. Additionally, established organizations and regimes at the international level prove highly influential to both formal and informal institutions and, in turn, impact decision-making outcomes at the regional, national, and local levels.

Identifying the actors involved in policy-making remains one of the more challenging elements. Inherent to policymaking or policy change in an industry that relies on regulation, government remains a central actor. Politicians hold final responsibility for passing new legislation, approving changes to existing law and providing direction to civil servants responsible for drafting the legislation. Thus, for any other actors interested in providing direction for legislation, influencing the decisions made through the political realm remains the most effective method. With this in mind, Teisman (2000: $\mathrm{p}$. 943) deems it critical to understand that, "Many actors are involved in decision-making, and they will introduce their own perceptions of relevant problems, possible solutions and political judgment ... Complex decision making involves many policy-makers who take decisions." Thus, only recognizing the traditional actors becomes limiting. For a case such as mining development, with economic, social, and environmental considerations at multiple levels of government, the policy path includes various stages with a multitude of stakeholders - some only involved for parts of the overall process. With the expansion of competing interests in mining development, the process must account for new actors, stakeholders, in the outcome and give them weight (Bryson 2004: p. 22; see Lebacqz 1986; Lewis 1991; and Stone 1997). While originally based in management and organization theory
(Freeman 1984), the term stakeholders now defines actors affected or interested in the outcome of a policy process. Defining stakeholders becomes critical as this explains who and what counts (Mitchell et al. 1997). For this study, the ability to act serves as a guide to discerning whether these stakeholders ought to be considered or not; Teisman (2000: p. 944) argues that actors develop a recognizable course of action - their attempt to influence the policy process. Because policy often encourages greater stakeholder inclusion, the importance of satisfying key stakeholders goes hand-in-hand, potentially determining the success or failure of public policy (Bryson 2004; Friedman 2000); it makes sense to include stakeholders as part of the group of pertinent policy actors.

Finally, analyzing the process of policy-making itself holds importance when researching a policy topic as complex as mining development. Differences in process, such as the order of events, can hold serious consequence on the outcome and final decision. For example, at what point the environmental impact assessment is conducted in the process can determine the quality of information available to those responsible for decision-making. Similarly, opening up for stakeholder participation and deliberation early in the process generates different results and possibilities for public input than inviting stakeholders to take part in the very last stages. So, while much of this analysis outlines the technicalities of the process and legal requirements, how they fit into the context and structure of the abovementioned institutions and actors matters, a great deal with regard to potential conflict and the subsequent bargains struck. Policy-making rather is a dynamic process incorporating a range of competing ideas, actors and actions, and where the outputs of decision-making are the result of spatially and temporally interconnected processes of negotiation and resource mobilization among actors from a variety of organizational affiliations (governmental authorities; industry; organized interests; and the general public) (Hall and McGinty 1997). Furthermore, initial policy creation involves multiple moving parts. Once implemented, most policy undergoes continuous review and revision through processes of policy change (Sabatier and Jenkins-Smith 1999; Sabatier 2007). 
Public policy thus enters a system of feedback loops (see Fig. 1 below), which can be either positive (self-reinforcing policy change) or negative (limiting further policy change). Therefore, when new policy is implemented, it unavoidably negotiates policy structures already in place, both in terms of the effects, consequences and ghostlike remnants of previously implemented political programs and formal institutions (Pressman and Wildavsky 1973) as well as the informal rules already established among the members of society in the shape of routines, customs, traditions, and conventions (North 1990). Although most policies cover time spans of a decade or more, often resulting in slow feedback since change typically comes as a result of an identified problem, the process of change remains an integral $\operatorname{cog}$ in the machine, worthy of study.

The relationship between institutions, actors, and process and the perception of mining are tied closely to the concept of social license to operate (SLO). The rules of the game, actors involved, and decision-making processes all include attempts to improve inclusiveness and build broader acceptance for mining operations, which is central to SLO.

These three facets - institutions, actors, and processesgive a broad overview of policy analysis but provide a solid foundation through which to review the existing research on land use such as mining. And, not only does this article aim to categorize the research, but it also looks to find the nuances in each category specific to issues of land use, environmental management, and benefit sharing.

The figure above outlines the relationship between the three aspects we focus on in this article. Importantly, it is not a temporal model; rather, it illustrates the flow of influence. First, because institutions build the broader context and structure, they largely determine which actors can participate. Second, actors use the resources and strategies available to them to impact the process (and outcomes), making decisions that affect its design. Third, the process of decision-making, shaped by institutions and fulfilled by actors, leads to the overall perception of the outcome in the case, mining. The perceptions that emerge shape institutions in the future, creating a continual feedback loop.

\section{Delimitations}

Mining, in its broadest sense, includes any activity that involves the extraction of a material. In an effort to build stronger comparability, this review focuses solely on mining related to ore extraction to ensure the environmental and societal policy issues remain similar. Therefore, it excludes activities related to oil and natural gas. Along with limiting the parameters of applicable activities, we outline the theoretical boundary.
The initial stage of the review is to gather recent academic and policy literature that captures the most recent and highly visible issues in Nordic mining. The purpose of this analysis is to link mining issues in Sweden and Finland to international experiences to both point to potential solutions for existing problems and avoid issues in the future. Discovering, describing, and categorizing all current social science research in the mining industry would prove a daunting task. Therefore, this review first, and foremost, limits the scope to the public policy process. Furthermore, because the existing literature on mining spans decades, includes a multitude of subject matters, and is often in the form of reports and internal documentation - thus, it is difficult to come across with conventional search methods - an exhaustive literature analysis remains impossible. Therefore, to further narrow the scope, the article focuses heavily on articles written within the last two decades in an effort to identify the current trends in mining research related to political, environmental, and socioeconomic policy issues.

Undoubtedly, the term public policy covers a wide breadth of research areas and topics. But, because policy process research on mining remains relatively underdeveloped, keeping the scope broad allows for the review to effectively paint a picture of the current research environment. Subsequently, in setting these parameters, this study excludes any technical or "hard" science research on mining except where and when it holds a close connection to policy matters. In addition, a vast number of government, corporate, and NGO studies exist that focus on the social, environmental, and economic impacts of mining, along with policy implications and recommendations. We intentionally attempt to avoid including these in this study, choosing instead to focus on traditional academic research. Nonetheless, some of the publications referenced later still fall within this aforementioned category of government, corporate, and NGO publication.

Instead, the material used in the study primarily consists of academic reports, books, and articles from international peerreview journals, principally collected through searches in two major databases: ProQuest and Web of Science. Connected to a large number of smaller databases covering a broad spectrum of scientific research (e.g., incorporating both the natural and social sciences), these two databases provide a solid overview of the subject, not only from a political science perspective but also from the view of other scientific disciplines. The review was carried out in two steps. First, a broad, nonspecific search was used to grasp of the scope of possibly relevant material. This helped indicate where current trends in research on mining policy lay and, as a result, informed us how to proceed with the more targeted searches. Second, a number of more specific searches were executed by using search terms found in the first search. This includes key words such as mining, minerals, and extractive industry in combination with the terms political science, policy, politics, 
institutions, government, environment, and corporate social responsibility. This review then categorized the results of these various searches into the policy category or categories each best fit and then drawing comparisons to some of the work done in other land use activities.

\section{Institutions}

Identifying the institutions related to mining goes hand-inhand with understanding the norms, values, and rules in the political, corporate, and societal realms. Responsible in helping shape the creation and change of formal and informal processes, institutions are influenced by and, in turn, influence various facets of society. Furthermore, viewed as institutions, political context and history vary across nations, states, and cultures, thus underscoring the importance of the spatial component of this study. While setting the framework for actors granted access to the process and the shaping of the process itself, institutions should be viewed as a temporal processthe contemporary rules, policy structures, and norms permeating society (Pierson 1996: p. 126). Institutions, as a reflection of the political mandate and societal values of the day, should place emphasis on issues of local socioeconomic development and environmental protection-particularly for land use that often requires approval from multiple levels of government and multiple government ministries and agencies. However, some suggest that institutions may act as barriers for politicians when considering these issues as expectations at the international level pressure decision-makers to value foreign investment over national interest.

In the Nordic context, one of the primary issues raised is the issue of mine ownership as Sweden and Finland experienced similar paths. Swedish mining was deregulated in the early 1990s and opened to international actors, a strategy to attract international expertise and foreign investments to strengthen the Swedish mining sector (Tano et al. 2016; Tarras Wahlberg 2014). The opening of the sector, combined with an increasing demand for minerals and metals, stimulated mineral-related activities in Sweden. In the 2000s, multiple mining projects were launched, some by junior companies (Tarras Wahlberg 2014; Knobblock and Pettersson 2010). This included an expansion of exploration activities throughout the country, with expenditure growing from just under 300 million SEK (37.7 million USD) in 2005 to a high of just under 800 million SEK (113.1 million USD) in 2011. At the same time, increasing production capacity in operating mines, re-starting old mines and, building entirely new mines (Tano et al. 2016). However, the rejuvenation of the industry came with some contention. Most notably, the main issues that continue to challenge the industry are the competing land uses and the effect on reindeer herding (Beland Lindahl et al. 2018; Haikola and Anshelm 2016), which now raises questions about the institutional structure. Because reindeer herding is intimately linked to Sami culture, the push for the inclusion and recognition of Sami rights in the legislation is either directly or indirectly related to minerals and mine development (Kløcker Larsen and Raitio 2019; Lawrence and Moritz 2019), which has been reflected in recent court rulings but not in legislation (Lawrence and Åhrén 2016; Elenius et al. 2017). At the same time, state agencies interpret legislation in different ways, leading to greater legal uncertainty for the sector moving forward (Poelzer 2019).

In Finland, the 1990s also marked an opening of mineral law to multinational companies (Lindborg 1996) but this coincided with a downturn in the industry and, once again, not until the twenty-first century did foreign companies invest in prospecting and the fortunes of the industry reverse (Hernesniemi et al. 2011; Tuusjärvi 2013). The influx of these multinational companies changed the scope of mining in the Nordic countries - bringing forward international standards and assessments. At the same time, once foreign companies began investing, domestic questions around taxation and royalties to both community and country emerged. Understanding how to connect mining to local benefits was part of the efforts towards regional socioeconomic development (Mononen and Sairinen 2020; Mononen and Suopajärvi 2016). Most prominent, however, in recent discussions is the issue of environmental protection. Initially spurred by a pond leak in 2012 at the Talvivaara Mine that allowed uranium and other toxic metals leach into the environment, concern increased significantly over the handling of environmental issues related to mining (Mononen 2015; Sairinen et al. 2017). Today, many of the discussions on managing the industry in the future are the issues of environmental management (Ruokonen and Temmes 2019) but, even further, understanding how mining fits into a broader perspective of local planning and impact assessment (Suopajärvi and Kantola 2019). Research internationally points to the experiences in other countries and the problems to avoid.

\section{Resource governance}

While some suggest that mining, as an activity and industry, naturally leads to negative environmental and social outcomes for local communities with little economic compensation, others argue that institutional design matter in relation to the magnitude of negative outcomes. The first school of thought associates view mining as one of the culprits of "Dutch Disease" and "resource curse"- the school of thought that believes resource-rich states often depend too heavily on resource revenue, limiting long-term economic growth because of the lack of investment in manufacturing in combination with the volatile nature of resource prices. Furthermore, Bebbington et al. (2008a: p. 909) contend that the mineral sector effectively positioned itself to limit the ability for government to govern - the instruments to ensure social and 
environmental protection either weakened or disabled. In a similar vein, Cox (1996) looked at what he viewed as a missed opportunity for the Australian government to develop a partnership with India in order to apply pressure to the corporate sector. He cites the lack of political will and, subsequently, the powers of the state that trumped national interest (ibid: p. 97). These examples point to the inherent weakness in most political institutions related to the mining industry-weaknesses that favor corporate interests over social and environmental. On the other hand, with institutions playing a central role in defining the process, others make the argument that not all institutional arrangements weaken state authority.

Butkiewicz and Yanikkaya (2010) and Moreen (2006) both study the causes and effects of this "curse" and what policy instruments exist that circumvent or prevent the problem. Independently, they conclude that weak institutional arrangements are the chief causes of the problems, and that an extensive revision of existing institutions may provide a more sustainable solution. The work conducted by Brunnschweiler and Bulte (2008: p. 250) goes even further to suggest that resource wealth, when properly accounted and distributed, facilitates positive developments for both the related institutions and the impacted economy. Whether the state holds the brunt of the responsibility for the current institutions remains a pertinent question and, perhaps more importantly, whether the state holds responsibility for leading institutional change.

\section{Environmental protection}

While environmental legislation and regulation provide clear direction regarding the activity related to mining, some of the bargains and processes that affect the behavior of mining companies occur outside formal structures. Because the institutional arrangements differ immensely between jurisdictions, the deal making on environmental issues between companies and communities offers an interesting topic of research. In countries where environmental regulation remains lax, mining companies that operate on a global scale employ industry "best practices" regardless of the local law. The research done by Armaha et al. (2011) on Ghana gives an example where weak institutional arrangements affect transparency and accountability; furthermore, this occurs to a degree that part of the CSR work done by mining companies in the country includes upholding environmental standards more stringent than the law. While cases like this may indicate a positive trend with regard to CSR, different company standards create variance in the environmental behavior within a country.

This disjointed institutional arrangement can place the onus on local communities to ensure mining companies follow some type of environmental protection protocol. But, as Bebbington and Bury (2009) and Zhu and Cherni (2009) found, as the communication between companies and communities breaks down, the problems become enhanced. In
Peru, the lack of coordination between state agencies responsible for mining, water, and local development severely limit the possibility of sustainable development (Bebbington and Bury 2009). For communities with little expertise in these areas, little government direction can prove to be quite detrimental. In China, a similar situation of reduced government oversight led to a regulatory framework that neglected environmental protection, despite the opportunity to include such measures with recent market reform (Zhu and Cherni 2009). These examples indicate a real need for government to set fairly rigorous environmental standards, but simultaneously raises interesting debate over the role of mining companies in defining these standards through CSR.

\section{Corporate-community relations}

In recent years, mining companies find themselves increasingly at odds with inhabitants living close to a mine and their ability to engage, interact, and compromise directly with locals, often indicates the overall success of the development. However, the research on corporate engagement remains in relative infancy. Dashwood (2007) considers the motives for adoption of CSRpolicies within mining companies and challenges the commonly held conception that global norms pressure companies into adopting CSR-policies and discusses the possibility of internal company pressure as an alternative explanation. In this sense, mining companies learn from past experiences and not attempt to be proactive instead of reactive. In another study, a mine development in New Caledonia, Horowitz (2010) focuses on how social affiliations affect how people perceive and choose to trust scientific information about environmental impact. In the given situation, it was not a matter of judging the credibility of a scientist or his work, but rather a matter of siding with your own affiliation. Long-term expectations of social and economic benefits of the mining project were, in turn, the basis for choice of affiliation for community members. One might imagine, then, that the capacity for community members to make informed decisions regarding resource development remains an issue, as information flow may not necessarily be open.

As expected, the strength of institutions plays a tremendous role in ensuring that the intended outcomes actually come to fruition. However, global interdependence and interconnectivity also play important roles. On one the hand, politicians may capitulate to the pressure of adjusting local markets to allow more foreign investment-sacrificing some control over social and environmental preservation. On the other hand, globalization forces companies looking to conduct business in multiple jurisdictions to establish environmental and community engagement practices that surpass some government regulation.

Institutions governing long-term planning and land use, therefore, shave several common threads. The investment climate and the administrative capacity matter significantly when 
considering the actual cost of development. As demonstrated in all three types of development, government policy creates clear incentives and disincentives related to cost-either directly through a tax or indirectly with environmental guidelines. Corporations also take into account local administrative efficiencies, or lack thereof, when considering investment in a new project. However, social cost also matters. In a trend similar to that found in mining development, the degree to which local stakeholders provide input continues to grow in importance for other long-term developments like wind power and hazardous waste storage. As a result, the outcomes differ significantly due to the institutional arrangements but actors, as they make decisions, can prompt change in institutions; therefore, they serve as another important basis of research.

\section{Actors}

Political actors traditionally hold the lead role in mining development largely, through either constitutional or legislative powers, because government possesses final decision-making on issues of land use, water use, resource extraction, taxes, royalties, and rents. However, as non-government entities demand greater accountability and inclusion in policy decisions - a trend not uncommon in today's era of policy - politicians look at new ideas in order to allow different inputs into the policy process. Actor resources are as follows: organizational capacity, access to power, activation of opinion support, and knowledge. Particularly because concepts such as SLO and FPIC are gaining prominence in the resource sector, mining notwithstanding, one of the important factors is understanding the extent to which these actors affect decision-making to make policy work efficiently.

One of the central discussions around mine development today is the recognition of traditional Sami herding regions and the opportunities for decision-making. In the Swedish mining and environmental legislation, Sami rights are poorly articulated and protected (Lawrence and Åhrén 2016; Elenius et al. 2017). Traditional Sami reindeer herding is viewed as a public interest and not as a property right. Furthermore, Swedish law does not recognize a state consultation duty over the Sami people and, subsequently, Sami are treated in legislation as another stakeholder and not as a property holder. The greatest opportunity for input comes through the EIA, both for the mining concession and environmental permit. Because legislation does not distinguish Sami use of land directly, practices have been developed over recent years so that the mining company normally do a more extensive "reindeer herding impact assessment" as part of the EIA. Similar work on understanding the ontological differences between the world of minerals and reindeer herding in Finland points to some of the inevitable conflicts that will emerge due to the opposing views on the land and its resources (Lassila 2018).
The challenge to reconcile these different worlds will be part of the on-going work in the mineral industry for the foreseeable future.

Shifting away from Indigenous actors, in Finland, there has been significant work on the part of government to align the mining industry into the national and EU vision for sustainability. The Finnish Ministry of Employment and the Economy developed an action plan to help facilitate this goal (TEM 2013) and the creation of a Network for Sustainable Mining occurred shortly thereafter (Yrjö-Koskinen 2015). These initiatives are intended to link technological development and environmental protection within the sector, sending a clear message that the impacts from mining are socially acceptable. And, in turn, research in Finland is focused on understanding the perception of mining at the national level (Jartti et al. 2020; 2017). Different combinations of state and market solutions for social issues are common throughout the mining industry and looking at practices abroad offers an interesting comparison of similar issues and solutions.

\section{Governing bodies}

As one would expect, the capacity of those in government and the governing structures they create account significantly decisions in the process of mining development. Distributing responsibility across multiple authorities in properly functioning administrations can mitigate risk and ensure a development process that not only follows the legal requirement but also accounts for variables specific to each project. In administrations where the political authorities lack proper coordination and either misunderstand or neglect such variables, conflict arises. In an overview of Papua New Guinea's mineral policy, James (1997) explores a situation where conflict emerged between state and provincial authorities concerning the allocation of risks and benefits between the two levels of government. Primarily, provincial and state authorities failed to agree on the terms for compensation for mineral development. The state, responsible for the distribution of exploration rights, remains entitled to returns from mineral developments while provincial authorities, though impacted by the negative externalities of mining operations to a significant degree, felt they did not receive due compensation - the basis for the conflict. Similar problems occurred in Peru, where administrative structure reform led to conflicts between state, private companies, and local authorities over the distribution of economic benefits. The lack of support from national institutions served as one of the main reasons the new decentralized mining policy incited local conflicts (Arellano-Yanguas 2011).

\section{Corporations}

Viewing the research of corporate practices through the policy lens shifts the focus away from the technical aspects of mining to the adoption and evolution of CSR and environmental 
sustainability practices. As stated earlier, public awareness of risks to the environment and the potential for cultural change in the community places new pressure on the mining industry to adopt expansive CSR policies. The literature on CSR in mining industry covers a broad spectrum of issues, e.g., CSR development and progress, conflicts between corporate and state policy, community engagement, company/community conflicts, and systems for handling grievances.

McMahon and Remy (2001) employ a comparative approach in their study of mining development and find a trend of open communication and a high level of transparency among all successful corporate ventures. Not only must mining companies develop strong relationships with state and local government but also build and foster trust with all affected stakeholders and find ways to account for their interests in the development process. Cameron (2009) and Cheshire et al. (2011) also examined these types of interactions between mining companies, local communities, and government authorities in the implementation process of CSR practices. Both studies highlight the potential difficulties of inviting more actors to sit at the table, but also point out the benefits of cooperation. A similar study by Gifford et al. (2010) identifies an emerging "industry-wide institutional environment" of CSR-practices focused on building local legitimacy in developing countries. Jenkins and Yakoleva (2006) study mining companies' practices of reporting on their environmental progress as a form of CSR. Unsurprisingly, a substantial gap exists between the "best" and the "worst" companies and they conclude that more collaboration and good leadership is needed to raise the standards of the lowest performing companies.

Looking at CSR as a partnership among companies, governments, NGOs, and other actors from civil society, Aaronson (2011) evaluates the Extractive Industries Transparency Initiative (EITI) as a means to reduce corruption within the mining industry of resource rich countries. Despite good participation in the project, the inability of the EITI to penalize non-compliance among members remains a barrier that reduces the opportunity to be effective. Other difficulties include concerns with insufficient information, building broader public participation and input, and divergent views on the purpose and aim of the project. However, as a relatively new initiative, the EITI holds the potential to empower members of civil society if membership eventually requires compliance.

\section{Indigenous participation}

Although the rights of Indigenous peoples typically differ from one jurisdiction to another, similarities in land rights and land use claims still offer interest points of comparison. As Indigenous rights increasingly come to the fore as a policy issue, more countries recognize the right for Indigenous people to participate in resource development, a "duty to consult" in Canada for example, that impacts their land or livelihood either directly or indirectly.

O'Faircheallaigh and Corbett (2005) explore rights that include economic compensation for development on Indigenous lands and a right to participate in the process of deliberation concerning the planning and management of a mine. In theory, by participating in the planning process, Indigenous people can ensure that proper concern is taken to their cultural, social, spiritual, and environmental heritage. The degree of participation and level of compensation are often a matter of negotiation between Indigenous groups and the mining companies, which on several occasions has put Indigenous groups in a somewhat disadvantageous position. Two studies, O'Faircheallaigh and Corbett (2005) and O'Faircheallaigh (2010), look at the contents and properties of these negotiated agreements. One issue they identify, the provision of economic compensation, places Indigenous communities in a difficult situation. Because economic compensation often requires confidential agreements, they legally bind members of the Indigenous community to officially support a planned project as part of the requirements for compensation. Furthermore, Indigenous communities that receive economic compensation from a mining company may also reduce government financial support as a result (O'Faircheallaigh 2002, 2010). This is particularly problematic when considering lump sum compensation upfront or a portion of future resource revenue. Financial compensation may also exacerbate existing problems of inequality within Indigenous communities and depending on the type of compensation and the social composition of the community this risk may be quite diverse in different communities (O'Faircheallaigh 1998).

In more serious cases, mining projects that intentionally or unintentionally ignore consultation and communication with Indigenous communities provide the foundation for conflict. In Guatemala, this proved to be the case when Indigenous groups, as a response to structural exclusion from decisionmaking, organized several protests. Unfortunately, these protests often ended in violent confrontations with the police (Yagenova and Garcia 2009). Although these types of issues continue to persist, recent trends suggest that, in some jurisdictions, change is coming, albeit slowly.

Howlett (2010) and O'Faircheallaigh (2006) both study changes in Australian Indigenous rights legislation designed to create new possibilities for Indigenous peoples to participate in decision-making in mineral development processes. Based not only on values of democracy and legitimacy, these changes create new economic possibilities for Indigenous peoples. However, both articles conclude that even though these changes in legislation and policies increased the influence for some Indigenous groups, problems remain. One of these problems is a perceived institutionalized hostility within the legal and political systems towards Indigenous rights and influence. In practice, this reduces the effectiveness of the legislative changes. Another problem Howlett points out is 
the focus on the progress and achievements overshadowing the existing problems. Looking at Indigenous involvement in Guatemala, Fulmer et al. (2008) discover some problems with legislation meant to govern large-scale mineral development. Even though much of recent legislation, policy, and CSRpolicies concerning Indigenous rights hold potential, the outcomes often fail to align with the aims. Just like in the two case studies discussed above, structural and institutional weaknesses constrain potential progress.

\section{Local communities}

With the establishment of new mines, the actors most significantly affected come from the local communities. As a result, they have the most to gain and the most to lose. The industry claims a track record of local economic growth that coincides with mining development, a sentiment often echoed by government, and frequently this holds true. However, the permanent change to the ecosystem and environment is also well documented. This impact spurs community actors to demand more diligence and attention from mining companies to ensure they keep damage to a minimum or, in some cases, completely reconsider the mine. Unsurprisingly, the emergence of conflicts, particularly legal battles, between local inhabitants and large multinational mining companies set up potential "David versus Goliath" scenarios.

A conflict between small-scale Peruvian farmers and a large international mining company saw the farmers "even out the odds" and increase their resistance by cooperating with national and international NGOs. Importantly, by reframing their claims from an international perspective, the farmers found new support for their cause (Haarstad and Fløysand 2007). Similar grassroots resistance movements occurred in Ecuador, and Kuecker (2007) described another example of the potential influence and power of community actors. In this case, local resistance groups, through protests, managed to stop the development of a new mine by ensuring the costs of development became too high. In one particular instance, villagers removed all the mining equipment from the extraction site, effectively stopping the mining company from operating.

\section{Process}

Requiring stringent legal procedure while at the same time involving various informal inputs, mining development continues to use more traditional and linear aspects of the policymaking while, at the same time, other aspects shift to a governance model based on the diffusion of responsibility. The conventional model of the policy process as a linear progression through a set of separated and functionally sequenced stages (i.e., problem formation, selection of policy, implementation, and evaluation) (de Leon 1999) is therefore not entirely adequate for capturing the shifting and uncertain patterns of governance characterizing contemporary mining policy processes. Rather, mining policy is a dynamic process incorporating a range of competing ideas, actors and actions, and where policy production is the result of spatially and temporally interconnected processes of negotiation and resource mobilization (Hall and McGinty 1997).

Sustainability as a concept and, in turn, as a policy goal, has gained significant prominence over the past three decades. The importance of creating policy that not only looks short term but also instead adopts a more comprehensive solution that considers the long-term implications for issues such as the environment, society, and economy now takes priority, at least in rhetoric. A clear example today of efforts towards long-term sustainability is the United Nations' Sustainable Development Goals (SDGs). The UN created 169 targets within 17 broad goals to guide member states towards a common vision for 2030 (United Nations 2015). While providing a framework and definition for sustainability that countries can latch onto, the SDGs also illuminate the inherent conflict within sustainability as contradictions can be identified within the targets (Guan et al. 2019), making the implementation of these goals one of the most difficult public policy challenges in our future (Xue et al. 2018). The SDGs become increasingly recognized within the public sphere, Sweden and Finland no exception (Eurobarometer 2017). Because the SDGs promote both socioeconomic growth and environmental protection, they reflect both the challenges related individual project and the decisions taken approving and monitoring a mine and the broader societal dilemmas between development and conservation. Sweden and Finland, as members of a EU that support these goals, must develop processes that reconcile these different views on sustainability and place mining in a position to contribute to these goals. Therefore, as the work begins realizing these goals, pressure mounts on authorities to chart strategies forward and develop capable policy.

However, this requires a rethinking of the factors governments and their respective bureaucracies must account for when applying these new policy principles. With the increased pressure for government to become more accountable and transparent when making these types of decisions, along with interested actors' demand for greater direct input, the nature of public policy-making, and even democracy, changes. Mining provides a useful case when considering the basic tenants of policy development and in deciding on whether the institutions and structures produce the intended results-including the process itself. And, although mining development alone lends well to the analysis of policy-making and assumptions can be made regarding the key aspects to investigate, an investigation of the policy process also speaks to other nonrenewable resource developments.

A transition to greater sustainability requires renewable energy as a centerpiece to reaching carbon neutrality (Avila 
2018). But the ambition for this type of sustainable future presupposes access to renewable natural resources and innovation-critical metals such as copper, cobalt, lithium, and rare earth elements for batteries, wind turbines, and solar cells (Tillväxtanalys 2017). Many of these elements are found in Sweden and Finland and, as a result, the European Commission designated these two nations as critical mineral regions. And the demand of critical metals increases rapidly as renewable energy infrastructures are built. Large-scale electrification of energy systems requires energy storage technologies that necessitate the extraction of "battery minerals" (Arrobas et al. 2017). Finding a process that adequately addresses these different perspectives is not new to the mining industry. However, looking at how the recognition of different values and methods to find collaborative arrangement may give insight on how to solve these sustainability conflicts in the future.

\section{Competing values}

Conflicts can arise between communities and the state (Lange 2011; Bebbington et al. 2008a), small- and large-scale miners (Hilson 2002b), within communities (Campbell and Roberts 2010), but also between communities and mining companies (Kemp et al. 2011; Bebbington and Williams 2008; Hilson 2002a), which seems to attract the most attention. If not mediated properly, these value conflicts possess the potential to escalate into full-scale confrontations between different factions, which can result in severe consequences both for the development process itself and for the affected communities. Commonly, these conflicts revolve around divergent views of the social, economic, environmental, and cultural effects mining have on the surrounding community and its inhabitants (e.g., Lange 2011; Kemp et al. 2011; Bebbington and Williams 2008). Contrary to this, Hilson (2002a) claims that these impacts rarely are the chief cause of conflict. Instead, he points to the lack of communication and information sharing between community members and mining companies as the biggest reason for conflict. Beyond improved communitycompany consultation and communication, an increased level of coordination between regional authorities and better compensation for communities also contribute to decreased levels of conflict (Ibid). Although these and other similar mechanisms offer the possibility to effectively avoid potential conflicts they also require extensive effort from both mining companies and community members. Without this engagement, the risk that attempts to transform high-level CSR into "on the ground practices" falls short of its intentions remains (Kemp et al. 2011).

Besides the design of the development process and the efforts of mining companies and community members, the type of intra-community communication also seems to affect the level of conflict during development. In an attempt to better understand the internal dynamics of a development process, Campbell and Roberts (2010) analyzed the discursive process surrounding the proposal of a new mine. They discovered a highly polarized debate involving two separate discursive communities, each trying to convince undecided community members to support their point of view. Despite extensive campaigning, neither side proved successful in converting members of the opposing faction, only undecided community members could be convinced. This signals a potential problem for companies trying to establish new mines in communities with a priori strong anti-mining groups (Ibid).

\section{Communication and consultation}

To avoid or mitigate conflict in the development of a new mine (or the closure of an old mine), effective communication between stakeholders often serves as a prerequisite (Richardson 2003; Kepore and Imbun 2011; Laurence 2006; McMahon and Remy 2001). Developments including deliberative processes between mining companies and other stakeholders also generate many positive outcomes for all concerned parties. Mining companies can, for example, gain increased support from stakeholders who they require support from (e.g., local communities and government authorities) and, as a result, from the economic benefits (Laurence 2006). However, to enjoy these positive effects, it remains imperative that the deliberative processes occur at the start of a new project; otherwise, the community develops the perception they merely serve as a means to gloss over negative impacts already inflicted (Kepore and Imbun 2011).

Although mineral development processes that include deliberative procedures more effectively avoid conflicts, this does not guarantee conflict-free development. To ensure that deliberative processes, once in place, proceed as efficiently as possible and lead to as good as possible results, stakeholders possess some knowledge of negotiation and mediation - they must be given the tools and resources needed to conduct a successful negotiation (Richardson 2003).

As the industry changes, with deliberation and transparency taking on new meaning, to be effective, the process must reflect this change as well. Thus, a common understanding of the project goals, along with the technical aspects, remains critical to any process that includes purposeful deliberation. Learning, in some capacity, then becomes a necessary part of the process and facilitating this between societies, governments, and industries requires a strong understanding of how different learning occurs (Smit et al. 2007). Szarka (2006) also points to the importance of keeping a wide breadth of aspects when thinking about learning. While understanding the economic aspects of resource development usually becomes the main focus, attention ought to be paid to learning the pertinent institutional and community factors. 


\section{Conclusion}

With the pressure for additional resources to meet future, clean energy needs, Sweden and Finland find themselves in an interesting position. Many of the minerals needed to supply the energy transition are found in these two northern European countries and, as the EU moves forward with its commitments such as the European Green Deal and the UN's Sustainable Development Goals, the pressure continues to mount to help meet these objectives. However, the ability for nations to create sustainable mining industries rests on policy that incorporates sound institutions, key actors, and proper processes. While both Sweden and Finland have been deemed attractive locales for investment by entities such as the Fraser Institute, there are current challenges that will be exacerbated with the need for new, critical minerals. Because institutions, actors, and processes play a central role in the effectiveness of an industry, looking at these components from an international perspective is vital to both dealing with problems today and preventing them in the future. Our findings on the current mining issues in Sweden and Finland confirm that attention must be placed across all three facets of policy development.

In both jurisdictions, similar issues around understanding and strengthening institutions will be critical. Corporations look to jurisdictions that provide conditions ideal for longterm investment. Governments that operate within a strong institutional framework find the task of generating revenue from outside investment relatively easy, while governments with weak institutions attempt to compete by creating favorable market conditions that lead to little domestic benefit. This means that as minerals related to the energy transition are mined, the global environmental benefit is not enoughlocal communities and the nation where the mines are must enjoy additional, often economic, benefits. Looking beyond revenue regarding institutions, our review found the important role the dynamic between corporations and communities plays in the success of mining operations, particularly with regard to Indigenous rights and environmental protection. While corporate engagement practices are key, government needs to provide some clarity for all actors on management of different land use activities - particularly when they overlap in a significant way. Defining the rights of Indigenous groups may be one method, but authorities need a coordinated interpretation of the existing legislation at the very least. One of the examples in the literature highlights the conflict between different levels of government and/or government agencies. Highly decentralized policy leads to competing goals within government, serving as one source of agent conflict. On the environmental side, effective corporate relations depend heavily on the level of communication between the company the community it wishes to engage. In projects where the company takes the lead on setting the environmental standards, community engagement is critical to establish and maintain trust. However, in jurisdictions with more rigorous standards, the research on the importance of outside input into environmental planning and protection in mining lags behind. Researching input into various environmental impact assessment processes offers a compelling point of comparison between countries like Australia, Canada, Sweden, and Finland. Because decision-making ability for actors relies heavily on the institutional framework, the research on pertinent actors in the mining industry paints a similar picture.

On actor side, the inclusion of Indigenous communities is one of the central issues in Sweden. And while industry engagement with Sami communities is not new, some of the challenges for new companies working in Sweden are similar to those found around the world. In Finland, the value of creating actor networks is central to gaining acceptance for the industry, particularly giving NGOs and grassroots organizations a place around the table. In the global examples, for Indigenous communities, because mine development often includes issues around land rights, the discussion revolves around responsibility for planning and revenue sharing. In some cases, Indigenous groups opt to broker deals directly with mining companies in order to receive compensation upfront. However, this leaves communities vulnerable to future problems with the mine after they sign the confidentiality agreements that go hand-in-hand with compensation packages. Both scenarios point to the significant variance for decision-making and, the unevenness of which, may hold the potential for conflict in the future. Grassroots organization sometimes displayed the capacity to overshoot their potential by finding sympathizers at the national or international level-important for policy-makers to consider as the influence of international convention grows. Sweden and Finland need to find a balance between appeasing interested actors while focusing on those most affected by mining operations. In all cases, the capacity for stakeholders interested in ensuring societal and environmental protection and safeguards largely correlates with institutions. The jurisdictions that either protects additional input through legislative measures or informal practices more effectively reduce conflict, and for the most part, these measures and practices are found in the process.

Finally, creating effective processes is ever more pertinent in a time when the pressure of meet energy and climate goals are increasing. For Sweden and Finland, meeting these targets while maintaining control of the impacts and benefits domestically is a necessity. And, with the on-going debates and policy change over environmental protection and competing land use, particularly Indigenous, the value of getting these decisions right is immense and governments have the capability to make changes to the process that elicit significant effect on the outcomes. Much of the research on mining policy deals with investigating potential points of conflict between actors, and due to institutions, the work on policy process focuses on 
conflict mitigation and management. The development of a mine requires many moving pieces and, as such, the likelihood of competing goals rises. Therefore, the strength of the process lies in its ability to allow necessary input throughout development and beyond, while possessing mechanisms that promote compromise and collaboration. As discussed in much of the policy literature, deliberation allows for greater accountability and, subsequently, acceptance. Sweden and Finland have a difficult task moving forward as multiple competing interests such as mineral production, Indigenous rights, and sustainability come to a head. However, past research point to the potential for sound policy development to not only mitigate conflict but to also find solutions beneficial to multiple parties.

Together, strong institutions, engaging affected actors, and effective processes make the difference between mining projects that contribute to both societal and community goals versus those that leave fail to maximize benefits. The need for more raw materials will essentially double by 2060 (OECD 2019), underscoring the importance of getting these factors right to position the Swedish and Finnish mining sectors to succeed in the coming century.

Funding Open access funding provided by Lulea University of Technology.

Open Access This article is licensed under a Creative Commons Attribution 4.0 International License, which permits use, sharing, adaptation, distribution and reproduction in any medium or format, as long as you give appropriate credit to the original author(s) and the source, provide a link to the Creative Commons licence, and indicate if changes were made. The images or other third party material in this article are included in the article's Creative Commons licence, unless indicated otherwise in a credit line to the material. If material is not included in the article's Creative Commons licence and your intended use is not permitted by statutory regulation or exceeds the permitted use, you will need to obtain permission directly from the copyright holder. To view a copy of this licence, visit http://creativecommons.org/licenses/by/4.0/.

\section{References}

Aaronson SA (2011) Limited partnership: business, government, civil society, and the public in the extractive industries transparency initiative (EITI). Public Adm Dev 31:50-63

Arellano-Yanguas J (2011) Aggravating the resource curse: decentralisation, mining and conflict in Peru. J Dev Stud 47(4):617-638

Armaha FA, Obirib S, Yawsonc DO, Afrifaa EKA, Yengohd GT, Olssone JA, Odoif JO (2011) Assessment of legal framework for corporate environmental behavior and perceptions of residents in mining communities in Ghana. J Environ Plan Manag 54(2):193209

Arrobas D, La Porta Hund KL, Mccormick MS, Ningthoujam J, Drexhage JR (2017) The growing role of minerals and metals for a low carbon future. Washington, D.C.: World Bank Group

Avila S (2018) Environmental justice and the expanding geography of wind power conflicts. Sustain Sci 13(3):599-616
Bebbington A, Bury J (2009) Institutional challenges for mining and sustainability in Peru. PNAS 106(41):17296-17301

Bebbington AJ, Williams M (2008) Water and mining conflicts in Peru. Mt Res Dev 28(3/4):190-195

Beland Lindahl K, Johansson A, Zachrisson A, Viklund R (2018) Competing pathways to sustainability? Exploring conflicts over mine establishments in the Swedish mountain region. J Environ Manag 218:402-415

Berman M, Loeffler R, Schmidt JI (2020) Long-term benefits to Indigenous communities of extractive industry partnerships: Evaluating the Red Dog Mine. Resources Policy, 66.

Bridge G (2004) Contested tertian: mining and the environment. Annu Rev Environ Resour 29:205-259

Brunnschweiler CN \& Bulte EH (2008) The resource curse revisited and revised: A tale of paradoxes and red herrings. J Environ Econ Manag 55(3):248-264

Bryson JM (2004) What to do when stakeholders matter: stakeholder identification and analysis techniques. Public Manag Rev 6(1):2153

Butkiewicz JL, Yanikkaya H (2010) Minerals, Institutions, openness, and growth: an empirical analysis. Land Econ 86(2):313-328

Cameron R (2009) Community and government effects on CSR: case studies of mining on Bolivia's Altiplano. Masters Abstracts International 28:05

Campbell G, Roberts M (2010) Permitting a new mine: insights from the community debate. Res Policy 35:210-217

Cesar, S., Jhony, O. (2020) Corporate social responsibility supports the construction of a strong social capital in the mining context: evidence from Peru. Journal of Cleaner Production, 267, art. no. 122162.

Cheshire L, Everingham J, Pattenden O (2011) Examining corporatesector involvement in the governance of selected mining-intensive regions in Australia. Aust Geogr 42(2):123-138

Cox D (1996) Argyle diamonds: the political economy of a lost resource. Aust J Polit Sci 31(1):83-88

Dashwood HS (2007) Canadian mining companies and corporate social responsibility: weighing the impact of global norms. Can J Polit Sci 40(1):129-156

de Leon P (1999) "The stages approach to the policy process: what has it done? Where is it going?" in Theories of the policy process, ed. Sabatier, P, A. University of California, Davis: Westview Press

Elenius L, Allard C, Sandström C (eds) (2017) Indigenous rights in modern landscapes: Nordic conservation regimes in global context. Routledge, New York

Eurobarometer. EU Citizens' Views on development, cooperation and aid. 2017. Available online: https://ec.europa.eu/europeaid/sites/ devco/files/ebs-476-report-20180925_en.pdf/. Accessed 10 September 2019

European Commission (2016) European Innovation Partnership on Raw Materials: Annual Monitoring Report 2016, EUR28839 EN, Publications Office of the European Union, Luxembourg.

Frederiksen T (2019) Political settlements, the mining industry and corporate social responsibility in developing countries. Extractive Industries and Society 6(1):162-170

Freeman RE (1984) Strategic management: a stakeholder approach. Pitman, Boston

Friedman T (2000) The Lexus and the olive tree: understanding globalization. Anchor, New York

Fulmer A, Snodgrass Godoy A, Neff P (2008) Indigenous rights, resistance, and the law: lessons from a Guatemalan mine. Latin American Politics and Society 50(4):91-121

Gifford B, Kestler A, Anand S (2010) Building local legitimacy into corporate social responsibility: gold mining firms in developing nations. J World Bus 45(3):304-311 
Guan T, Meng K, Lui W, Xue L (2019) Public attitudes toward sustainable development goals: evidence from five Chinese cities. Sustainability 11(20):5793

Haarstad H, Fløysand A (2007) Globalization and the power of rescaled narratives: a case of opposition to mining in Tambogrande, Peru. Polit Geogr 26:289-308

Haikola S, Anshelm J (2016) Swedish mineral policy at a crossroads?: critical reflections on the challenges with expanding Sweden's mining sector. The Extractive Industries and Society 3(2):508-516

Hall PM, McGinty PJW (1997) Policy as the transformation of intentions: producing program from statute. The Sociological Quartely 38(3): 439-467

Hernesniemi, H., Berg-Andersson, B., Rantala, O., Suni, P. (2011) Kalliosta Kullaksi-Kummusta Klusteriksi. Suomen Mineraaliklusterin Vaikuttavuusselvitys. Elinkeinoel" am" an tutkimuslaitos ETLA, Helsinki.

Hilson G (2002a) An overview of land use conflicts in mining communities. Land Use Policy 19:65-73

Hilson G (2002b) Land use competition between small- and large-scale miners: a case study of Ghana. Land Use Policy 19:149-156

Hilson A, Hilson G, Dauda S (2019) Corporate social responsibility at African mines: linking the past to the present. J Environ Manag 241: 340-352

Horowitz LS (2010) "Twenty years is yesterday": science, multinational mining, and the political ecology of trust in New Caledonia. Geoforum 41:617-626

Howlett C (2010) Indigenous agency and mineral development: a cautionary note. Studies in Political Economy 85:99-123

James N (1997) An overview of Papua New Guinea's mineral policy. Res Policy 23(1/2):97-101

Jartti T., Litmanen T., Lacey J. \& Moffat K. (2017) Finnish attitudes toward mining. Citizen Survey - 2016 results. University of Jyväskylä and Mineral Resources Business Unit, Commonwealth Scientific \& Industrial Research Organization. University of Jyväskylä, Jyväskylä.

Jartti T, Litmanen T, Lacey J, Moffat K (2020) National level paths to the mining industry's social licence to operate (SLO) in Northern Europe: the case of Finland. Extractive Industries and Society 7(1):97-109

Jenkins H, Yakovleva N (2006) Corporate social responsibility in the mining industry: exploring trends in social and environmental disclosure. J Clean Prod 14:271-284

Kemp D, Owen JR, Gotzmann N, Bond CJ (2011) Just relations and company-community conflict in mining. J Bus Ethics 101:93-109

Kepore K, Imbun BY (2011) Mining and stakeholder engagement discourse in a Papua New Guinea mine. Corp Soc Responsib Environ Mgmt 18:220-233

Kløcker Larsen R, Raitio K (2019) Implementing the state duty to consult in land and resource decisions: perspectives from Sami communities and Swedish State Officials. Arctic Review 10:4-23

Knobblock E, Pettersson Ö (2010) Restructuring and risk-reduction in mining: employment implications for northern Sweden. Fennia International Journal of Geography 188(1):61-75

Kuecker GD (2007) "Fighting for the forests: grassroots resistance to mining in Northern Ecuador." Lation American Perspectives, 153/ 34 (2):94-107

Lange S (2011) Gold and governance: legal injustices and lost opportunities in Tanzania. Afr Aff 110(439):233-252

La Porta AD, Hund KL, Mccormick MS, Ningthoujam J, Drexhage JR (2017) The Growing Role of Minerals and Metals for a Low Carbon Future. Washington, D.C.: World Bank Group.

Lassila MM (2018) Mapping mineral resources in a living land: Sami mining resistance in Ohcejohka, northern Finland. Geoforum 96:19

Laurence D (2006) Optimization of the mine closure process. J Clean Prod 14:285-298
Lawrence R, Åhrén M (2016) "Mining as colonisation: the need for restorative justice and restitution of traditional Sami Lands" Head L, Saltzman S, Setten G and Stenseke M (eds) Nature, temporality and environmental management: Scandinavian and Australian Perspectives on Landscapes and Peoples. Taylor and Francis, UK

Lawrence R, Moritz S (2019) Mining industry perspectives on indigenous rights: corporate complacency and political uncertainty. Extractive Industries and Society 6(1):41-49

Lebacqz K (1986) Six theories of justice. Augsburg Publishing House, Minneapolis

Lesser P, Gugerell K, Poelzer G, Hitch M, Tost M (2020) European mining and the social license to operate. The Extractive Industries and Society 787

Lewis C (1991) The ethics challenge in public service: a problem-solving guide. Jossey-Bass, San Francisco

Lindborg T (1996) Suomalaisen kaivosklusterin rakennemuutos [The structural change of the Finnish Mining Cluster, in Finnish]. Studies of the Department of EconomicsNo. 36. University of Oulu, Oulu.

March JG, Olsen JP (2006) "Elaborating the 'New Institutionalism," in The Oxford handbook of political institutions edited by Rhodes, R. A. W., Binder, S. A., and Rockman, B. A. Oxford University Press, Oxford

McMahon G, Remy F (eds) (2001) Large mines and the communitysocioeconomic and environmental effects in Latin America, Canada, and Spain. International Research Development Centre, Canada

de-Miguel-Molina B, Chirivella-González V, García-Ortega B (2019) CEO letters: social license to operate and community involvement in the mining industry. Business Ethics 28(1):36-55

Mitchell RK, Agle BR, Wood DJ (1997) Toward a theory of stakeholder identification and salience: defining the principle of who and what really counts. Acad Manag Rev 22(4):853-886

Moffat K, Zhang A (2014) The paths to social licence to operate: an integrative model explaining community acceptance of mining. Res Policy 39:61-70

Mononen T (2015) Jos olisi tavallinen kaivos-Talvivaaran kaivoshankkeen ymp" arist" ovaikutukset paikallisten kokemana (If it only would be a normal mine-Experienced environmental impacts in local level). Terra 127(3):113-124

Mononen T, Sairinen R (2020) Mining with social license: case study of Kylylahti mine in Northern Karelia. Finland, The Extractive Industries and Society

Mononen T, Suopajärvi L (eds) (2016) Kaivos suomalaisessa yhteiskunnassa (Mining in Finnish Society). Lapland University Press, Rovaniemi

Moreen AL (2006) Overcoming the 'resource curse': prioritizing policy interventions in countries with large extractive industries. $\mathrm{PhD}$ Thesis: RAND Corporation.

North D (1990) Institutions, institutional change and economic performance. Cambridge University Press, Cambridge

North D (1991) Institutions. J Econ Perspect 5(1):97-112

O'Faircheallaigh C (1998) Resource development and inequality in indigenous societies. World Dev 26(3):381-394

O'Faircheallaigh C (2002) Denying citizens their rights? Indigenous people, mining payments and service provision. Aust J Public Adm 63(2):42-50

O'Faircheallaigh C (2006) Aborigines, mining companies and the state in contemporary Australia: a new political economy or 'business as usual'? Aust J Polit Sci 41(1):1-22

O'Faircheallaigh C (2010) Aboriginal-mining company contractual agreements in Australia and Canada: implications for political autonomy and community development. Canadian Journal of Development Studies 30(1-2):69-86 
O'Faircheallaigh C, Corbett T (2005) Indigenous participation in environmental management of mining projects: the role of negotiated agreements. Environmental Politics 14(5):629-647

OECD (2019) Global Material Resources Outlook to 2060: Economic Drivers and Environmental Consequences. OECD Publishing, Paris

Ofori JJY, Ofori DR (2019) Earning a social license to operate: perspectives of mining communities in Ghana. Extractive Industries and Society 6(2):531-541

Peters BG (2005) Institutional theory in political science, 2nd edn. Continuum, London

Pierson P (1996) The path to European integration: a historical institutionalist approach. Comparative Political Studies 29(2):123-163

Poelzer GA (2019) A view from the top: state perspectives on legitimacy and the mine development process. Environ Sci Policy 94:32-38

Pressman JL, Wildavsky A (1973) Implementation. University of California Press, Los Angeles

Richardson R (2003) Governing western mineral resources: the emergence of collaboration. Nat Resour J 43:561-586

Robinson LM, Fardin J, Boschetti F (2020) Clarifying the current role of a social licence in its legal and political context: An examination of mining in Western Australia. Resources Policy 67:101649

Ruokonen E, Temmes A (2019) The approaches of strategic environmental management used by mining companies in Finland. J Clean Prod 210:466-476

Sabatier PP (2007) Theories of the policy process, 2nd edn. Westview Press, Boulder

Sabatier PA, Jenkins-Smith HC (1999) The advocacy coalition framework: an assessment. In: Sabatier P, Boulder A (eds) Theories of the policy process. Westview Press, Colorado

Sairinen R, Tiainen H, Mononen T (2017) Talvivaara mine and water pollution: an analysis of mining conflict in Finland. Extractive Industries and Society 4(3):640-651

Sícoli Pósleman C, Sallan JM (2019) Social license to operate in the mining industry: the case of Peru. Impact Assessment and Project Appraisal 37(6):480-490

Smit T, Junginger M, Smits R (2007) Technological learning in offshore wind energy: different roles of the government. Energy Policy 35: 6431-6444

Stone D (1997) Policy paradox and political reason. W.W. Norton, New York

Suopajärvi L, Kantola A (2019) The social impact management plan as a tool for local planning: case study: mining in Northern Finland. Land Use Policy 104046
Szarka J (2006) Wind power, policy learning and paradigm change. Energy Policy 34:3041-3048

Tano S, Pettersson Ö, Stjernström O (2016) Labour income effects of the recent "mining boom" in northern Sweden. Res Policy 49:31-40

Tarras-Wahlberg NH (2014) Social license to mine in Sweden: do companies go the extra mile to gain community acceptance? Miner Econ $27: 143-147$

Teisman G (2000) Models for research into decision-making processes: on phases, streams and decision-making rounds. Public Adm 78(4): 937-956

Thomson I, Boutilier RG (2011) Social license to operate. In: Darling P (ed) SME mining engineering handbook. Society for Mining, Metallurgy and Exploration, Littleton, pp 1779-1796

Tillväxtanalys (2017) 'Innovation-critical metals \& minerals from extraction to final product', Report 3/2017, Swedish Agency for Growth Policy Analysis: Östersund.

Tuusjärvi M (2013) From a mine to you-sustainability of the Finnish mining sector in the context of global supply chains of metals. Academic Dissertation. Department of Geosciences and Geography, A23, Faculty of Science. University of Helsinki, Helsinki

United Nations (2015) Transforming our world: the 2030 Agenda for Sustainable Development. 2015. https://sustainabledevelopment. un.org/content/documents/21252030\%20 Agenda\% 20 for $\%$ 20Sustainable\%20Development\%20web.pdf. Accessed 23 March 2020

Xue L, Weng L, Yu H (2018) Addressing policy challenges in implementing sustainable development goals through an adaptive governance approach: a view from transitional China. Sustain Dev $26: 150-158$

Yagenova SV, Garcia R (2009) Indigenous people's struggles against transnational Mining companies in Guatemala: the Sipakapa people vs GoldCorp Mining Company. Social Democr 23(3):157-166

Yrjö-Koskinen E (2015) Building trust in Finnish mining activities. Euromines Newsletter 2 Retrieved from: http://www.euromines. org/news/newsletters/2-2015/building-trust-finnish-miningactivities Accessed 15 Dec 2020

Zhu S, Cherni JA (2009) Coal mining in China: policy and environment under market reform. International Journal of Energy Sector Management 3(1):9-28

Publisher's note Springer Nature remains neutral with regard to jurisdictional claims in published maps and institutional affiliations. 